\title{
Vasopressin is life threatening for horses under isoflurane anaesthesia
}

\author{
Bettina Wollanke, Rebekka Reimold and Hartmut Gerhards \\ Klinik für Pferde der LMU München, Lehrstuhl für Innere Medizin und Chirurgie des Pferdes sowie für gerichtliche Tiermedizin
}

\begin{abstract}
Summary: The aim of the study was to examine the effects of vasopressin on the cardiovascular system of horses under isoflurane anaesthesia. For this purpose ten horses of various breeds were taken which had to be euthanized under general anaesthesia. Decision for euthanasia was made either during surgery or during radiographic examination due to diagnosis of a fatal condition. The horses consisted of

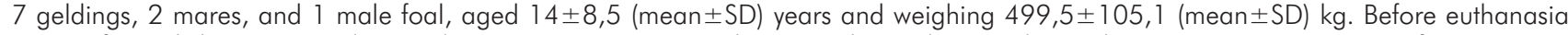
was performed during general anaesthesia, vasopressin was administered. Five horses obtained an intravenous injection of 0,2IU vasopressin/ $\mathrm{kg}$ and five horses were given an infusion of 0,08IU vasopressin $/ \mathrm{kg}$ minute over a 10 minute period. Mean arterial blood pressure, heart rate, colour of mucous membranes, capillary refill time, ocular reflexes, ECG, and respiratory frequency and volume were determined. Furthermore, arterial blood gas analysis, capnography and pulse oximetry were performed. Additionally, cardiac ultrasound and heart auscultation were conducted in four horses. The results were that the blood pressure increased within 30-60 seconds of vasopressin administration and that all horses developed a high degree of ischemia of the mucous membranes during the 30-60 seconds after either vasopressin injection or vasopressin infusion. Eight horses died due to cardiac failure. Cardiac arrest occurred in four horses within 5 minutes of vasopressin injection as well as in four horses during the 10 minutes of vasopressin infusion. In four horses an ultrasound examination during vasopressin administration revealed acute cardio dilation causing cardiac arrest. It can be concluded that Vasopressin is fatal for horses under general anaesthesia. The use of vasopressin must be avoided in horses. Vasopressin must not be used as an alternative drug for adrenaline in horses.
\end{abstract}

Keywords: Vasopressin / horse / isoflurane anaesthesia / cardiac dilation / cardiac arrest / lethal / anesthesiology

Citation: Wollanke B., Reimold R., Gerhards H. (2015) Vasopressin is life threatening for horses under isoflurane anaesthesia. Pferdeheilkunde 31, 341-345

Correspndence: PD Dr. Bettina Wollanke, Universität München, Klinik für Pferde, Veterinärstraße 13, 80539 München, Germany, E-Mail: b.wollanke@lmu.de

\section{Introduction}

The risk of fatal anaesthetic emergencies in horses is much higher than in small animals or human beings. Approximately 0,2\% (Czupalla and Gerhards 2013) up to 1\% of horses suffer from unexpectedly anaesthesia-related death (Johnston et al. 2004). In small animals, the anaesthesia-related mortality is 1 in 1,000 dogs or cats (Dyson et al. 1998). In humans, only $0,0004 \%$ of patients die during general anaesthesia from anaesthesia-related complications (ASA 2013).

As the anaesthetic risk in horses is relatively high, identification and use of the safest anaesthetic drugs as well as of the safest emergency drugs is extremely important. In horses, adrenaline is still the first drug of choice for the treatment of life threatening cardiovascular emergencies during general anaesthesia. As cardiac arrhythmias are one of the possible side-effects of the use of adrenaline during halothane and isoflurane anaesthesia, alternative drugs would be preferable.

Vasopressin is a peptide hormone (anti diuretic hormone, $\mathrm{ADH}$ ) with varying functions. One important effect of vasopressin is vasoconstriction. In human medicine, vasopressin is used for the management of vasodilatory shock and cardiac arrest (Wenzel et al. 2001, Johnson 2003, Wenzel et al. 2004, Krismer et al. 2006). It is said to be superior to epinephrine during cardiopulmonary resuscitation (Biondi-Zoccai et al. 2003, Krismer et al. 2006). In animal experiments, vasopressin seems to be superior to epinephrine for the treatment of haemorrhagic shock and for cardiopulmonary resu- scitation (Mulligan et al. 1997, Babar et al. 1999, Wenzel et al. 1999, Mayr et al. 2001, Schmittinger 2003, Stadlbaver 2003a and b, Raedler et al. 2004, Wetzel et al. 2004, Schmittinger et al. 2005, Dickey et al. 2010). The use and the clinical benefits of vasopressin in adult horses during CPR have not been determined (Muir and Hubbel 2009). The benefit of vasopressin is discussed controversial (Valverde et al. 2006, Hurcombe et al. 2008, Dembek et al. 2014). Some authors even do not mention vasopressin when listing vasopressors (Holcombe 2006). Since 2013 vasopressin even is on the "positive list" (list of substances essential for the treatment of equidae).

The aim of this study was to evaluate the effects of vasopressin in adult horses under general anaesthesia. The objective was to examine, whether vasopressin could be used as an alternative drug to epinephrine, without the side effects of cardiac arrhythmias, and whether it could be used for the management of cardiovascular emergencies in horses during general anaesthesia.

\section{Materials and Methods}

Ten horses of various breeds, which had to be euthanized under general anaesthesia. The horses consisted of 7 geldings, 2 mares, and 1 male foal, aged $14 \pm 8,5$ (mean \pm SD) years and weighing 499,5 $\pm 105,1$ (mean \pm SD) $\mathrm{kg}$ (Table 1). The decision for euthanasia was made either during surgery 
or during radiographic examination due to diagnosis of a fatal condition (Table 1). Before euthanasia was performed during general anaesthesia, vasopressin (PitressinÒ, Vasopressin Injection, USP, American Regent, INC., Shirley, NY 11976 ) was administered. One horse (horse No. 1) received the injection after increasing the anesthetic depth until mean arterial blood pressure was only $40 \mathrm{mmHg}$. The other 9 horses had a mean arterial blood pressure of a minimum of $60 \mathrm{mmHg}$ when vasopressin was administered. Horse number 10 received etilefrin 15 minutes before vasopressin was given and had a blood pressure of $110 \mathrm{mmHg}$.

Five horses received an intravenous injection of 0,2 IU vasopressin $/ \mathrm{kg}$ and five horses were given an infusion of $0,08 \mathrm{IU}$ vasopressin $/ \mathrm{kg} /$ minute over a 10 minute period. Mean arterial blood pressure measured by anaeroid manometry, heart rate, colour of mucous membranes, capillary refill time, ocular reflexes, ECG, and respiratory frequency and volume were determined every 30 seconds. Arterial blood gas analysis was conducted every 60 seconds and capnography and pulse oximetry were performed and noted every 30 seconds. In four horses (horses 4, 5, 6 and 7), cardiac ultrasound and heart auscultation were additionally conducted.

\section{Results}

In all 10 horses, the mucous membranes developed a very pale colour after the vasopressin administration (Fig. 1 and 2). This pallor appeared within 30 to 60 seconds after the injection of vasopressin. In the horses with vasopressin infusion, the pale colour of the mucous membranes was obvious within 90-120 seconds after beginning the infusion and after 210 240 seconds the mucous membranes seemed to be completely bloodless. During this time pulse oximetry was no longer possible due to the ischemia of the tongue. The capillary refill time was at first prolonged and was finally no longer detecta- ble. There was a temporary increase in blood pressure after vasopressin administration (Fig. 3 and 4), but it was notable that the needle of the aneroid manometer remained static which indicated loss of heart beat. Thus, there was no differen-

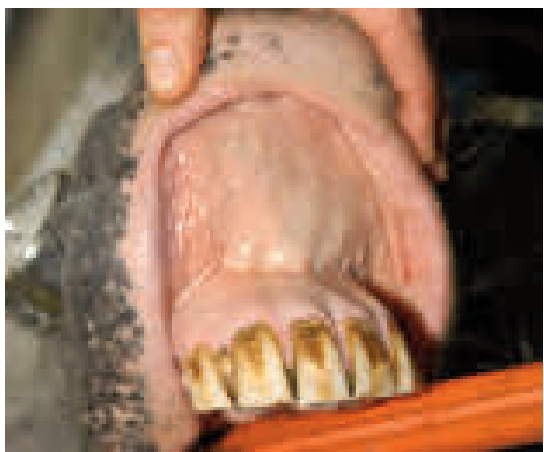

Fig. 1 Physiological colour of the mucous membranes prior to vasopressin administration | Physiologische Schleimhautfarbe vor der Gabe von Vasopressin.

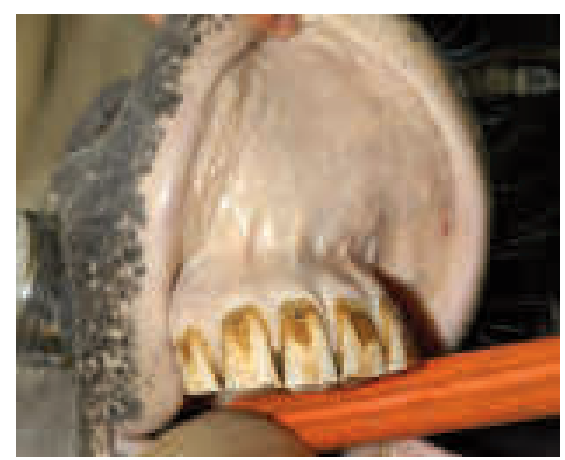

Fig. 2 Pallor due to ischemia of the mucous membranes, which developed within one minute after vasopressin injection and within 2-3 minutes after beginning the vasopressin infusion. | Ischämische Blässe der Schleimhäute, die sich innerhalb einer Minute nach der Vasopressininjektion und 2-3 Minuten nach Beginn der Vasopressininfusion entwickelt hat.

Table 1 Horses, which were treated with vasopressin during isoflurane anaesthesia. | Pferde, die während einer Isoflurannarkose Vasopressin erhalten haben.

\begin{tabular}{|c|c|c|c|c|c|c|c|c|}
\hline Horse & $\begin{array}{c}\text { age } \\
\text { [years] }\end{array}$ & breed & sex & $\begin{array}{c}\text { weight } \\
{[\mathrm{kg}]}\end{array}$ & reason for euthanasia & $\begin{array}{l}\text { vasopressin } \\
\text { administration }\end{array}$ & $\begin{array}{l}\text { dosage } \\
{[\mathrm{IU} / \mathrm{kg}]}\end{array}$ & outcome \\
\hline 1 & 15 & Arab & mare & 450 & $\begin{array}{l}\text { one eye blind due to ERU, second eye } \\
\text { corneal perforation, retinal detachment } \\
\text { (ultrasound during general anaesthesia) }\end{array}$ & injection & 0,2 & exitus letalis \\
\hline 2 & 4 & $\begin{array}{l}\text { Standard- } \\
\text { bred }\end{array}$ & mare & 508 & $\begin{array}{l}\text { limb trauma, severe infection of the coffin } \\
\text { joint and the navicular bursa }\end{array}$ & injection & 0,2 & exitus letalis \\
\hline 3 & 26 & Haflinger & gelding & 435 & $\begin{array}{l}\text { retroorbital tumor, beginning infiltration of } \\
\text { the brain (diagnosis with MRI) }\end{array}$ & injection & 0,2 & exitus letalis \\
\hline 4 & 12 & Warmblood & gelding & 612 & radiology of the hip joint, severe arthrosis & injection & 0,2 & exitus letalis \\
\hline 5 & 0,5 & Trakehner & stallion & 250 & $\begin{array}{c}\text { ataxia, myelography, severe compression of } \\
\text { the spinal cord }\end{array}$ & injection & 0,2 & euthanasia \\
\hline 6 & 27 & Warmblood & gelding & 600 & laparotomy, intraabdominal tumor & infusion & $0,08 /$ minute & exitus letalis \\
\hline 7 & 24 & Warmblood & gelding & 560 & radiology, pelvic fracture & infusion & $0,08 /$ minute & exitus letalis \\
\hline 8 & 14 & Warmblood & gelding & 500 & $\begin{array}{l}\text { ataxia, radiology, severe arthrosis of the } \\
\text { cervical vertebrae }\end{array}$ & infusion & $0,08 /$ minute & exitus letalis \\
\hline 9 & 12 & Warmblood & gelding & 560 & $\begin{array}{c}\text { chronic lameness, radiology, cystic lesion in } \\
\text { the stifle joint }\end{array}$ & infusion & $0,08 /$ minute & exitus letalis \\
\hline 10 & 11 & Warmblood & gelding & 520 & $\begin{array}{c}\text { back problems, radiology, severe lesions of } \\
\text { the spinal processes }\end{array}$ & infusion & $0,08 /$ minute & euthanasia \\
\hline
\end{tabular}


ce between systolic and diastolic blood pressure. Heart rate, respiratory rate, ocular reflexes, and arterial blood gas analysis as well as capnography did not change during the first minutes after the vasopressin injection or infusion. Auscultation showed cessation of heart activity within 30-180 seconds in 3 horses. In the fourth horse, the heartbeat was very quiet for several minutes but could be noticed until euthanasia (horse No. 5). Ultrasound examination revealed a severe cardiac dilatation within 50 seconds after the vasopressin administration leading to cardiac arrest in 3 of the 4 horses with cardiac ultrasound control (Fig. 5 and 6). Eight of the ten horses died from cardiac arrest within 5 minutes of vasopressin administration. Only two horses (horses No. 5 and 10) survived more than 10 minutes and were euthanized 690 seconds after the vasopressin injection or infusion respectively.

\section{Discussion}

The results of this study show that vasopressin is fatal to horses under isoflurane anaesthesia within a few minutes. The recommended dosage for horses differs a lot. The following dosages are recommended by some authors: $0,4-0,8 \mathrm{IU} / \mathrm{kg}$ bwt (Kirker 2003), 0,4-0,6 IU/kg bwt (Muir and Hubbel 2009), $0,3 \mathrm{IU} / \mathrm{kg}$ IV as a single dose (Stashak and Theoret 2008), 0,05 to $0,4 \mathrm{lU} / \mathrm{min} /$ adult horse, alternatively

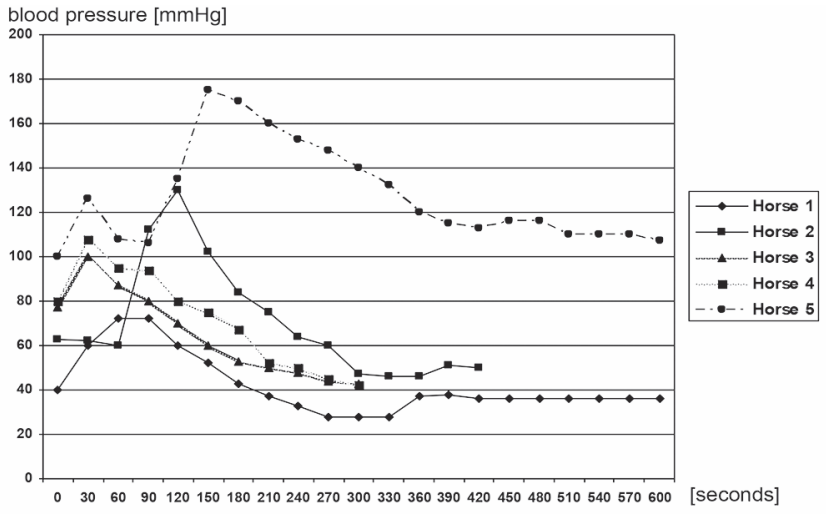

Fig. 3 Blood pressure after vasopressin injection. The injection was given at 0 seconds. | Blutdruck nach der Vasopressininiektion. Die Injektion wurde bei O Sekunden gegeben.

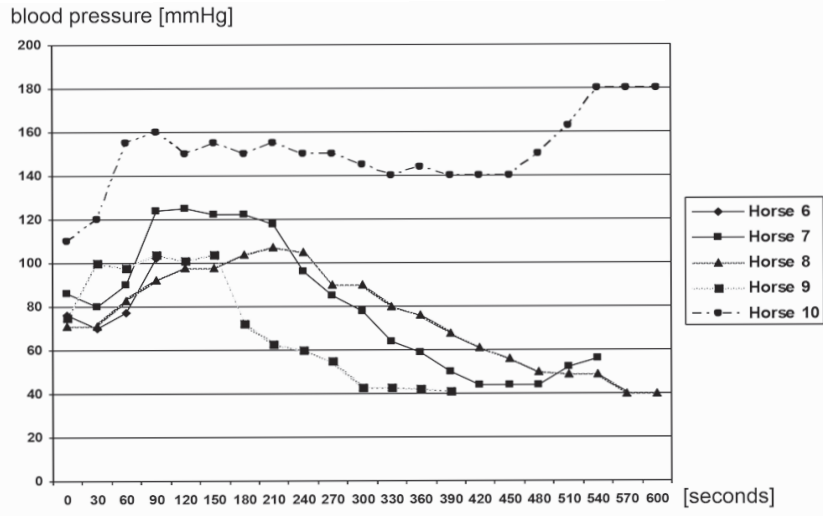

Fig. 4 Blood pressure during the vasopressin infusion. The infusion was started at 0 seconds. | Blutdruck während der Vasopressininfusion. Die Infusion wurde bei O Sekunden begonnen.
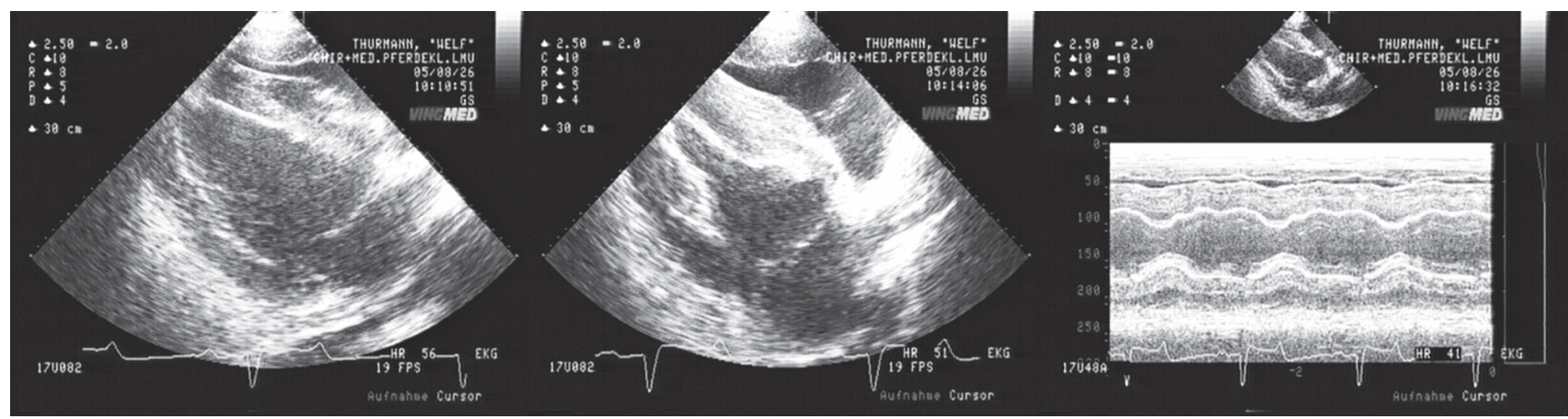

Fig. 5 Cardiac ultrasound before vasopressin administration. Left: diastole, middle: systole, right: M-mode. A physiological contraction of the left ventricle can be seen during systole. | Herzultraschall vor der Vasopressingabe. Links: Diastole; Mitte: Systole; Rechts: M-Mode. Während der Systole ist die physiologische Kontraktion des linken Venrtikels zu sehen.
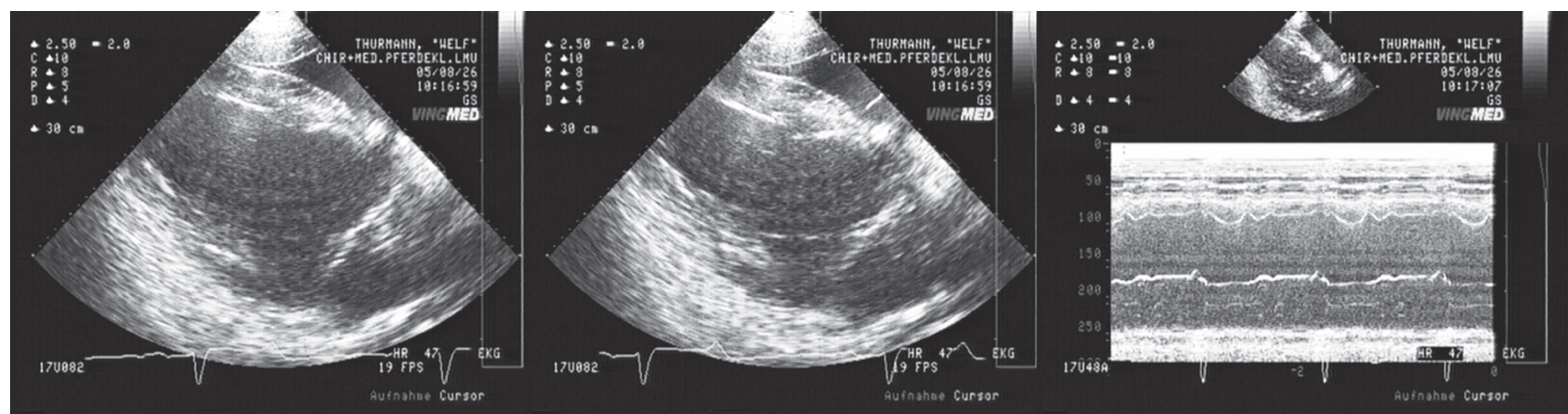

Fig. 6 Cardiac ultrasound 30 seconds after vasopressin injection. Left: diastole, middle: systole, right: M-Mode. There is no effective contraction of the heart visible during systole. The M-mode picture shows cardiac dilatation and almost complete lack of cardiac movement. Herzultraschall 30 Sekunden nach der Vasopressingabe. Links: Diastole; Mitte: Systole; Rechts: M-Mode. Während der Systole ist keine effektive Herzkontraktion mehr vorhanden. Auf dem M-Mode Bild ist eine Herzdilatation und das Fehlen von Herzbewegungen erkennbar. 
0,3-1 mU/ kg/min (Divers 2008), and in foals $0,25-0,5 \mathrm{mU} / \mathrm{kg}$ bwt (Kolm and Fey 2011) and 0.4 U/kg bwt (Emergency Drug Charts 2008). Surprisingly, the different dosages proposed from Stashak and Theoret (2008), Divers (2008), and the Emergency Drug Charts (2008) can be found in one single book.

Despite the relatively low dosage applied in this study $(0,2 \mathrm{lU} / \mathrm{kg}$ bwt for injection and $0,08 \mathrm{lU} / \mathrm{kg} \mathrm{bwt} / \mathrm{minute}$ for infusion respectively), 8 of 10 horses died within a few minutes. This result is in contrast to several studies in other species, in which vasopressin was showed to be superior to adrenaline in emergency cases (Mayr et al. 2001, Aung and Htay 2005, Krismer et al. 2006, Palmer 2007). The fatal effect in horses seemed to be a consequence of considerable peripheral vasoconstriction leading to acute cardiac dilation and finally cardiac arrest (Reimold 2006).

Additional studies could be performed to find an appropriate dosage for horses. It is possible that a very low dosage might have some beneficial effects. Still, vasopressin remains a dangerous drug for horses. In emergency situations, the narrow therapeutic margin and the danger of using a dose known from other species can easily lead to an overdose of vasopres$\sin$ in the horse. Thus, vasopressin must be considered a dangerous drug for horses and adrenaline is still the agent of choice in treating emergency cases during equine anaesthesia.

It remains unknown why vasopressin has this fatal effect on the horse. As horses are flight animals, the cardiovascular system of horses is capable of very high performance. They are able to switch from sleep to very high performance in a moment. One possible explanation for the very effective peripheral vasoconstriction in horses could be that there are a high amount of vasopressin receptors in the peripheral vessels causing extreme vasoconstriction. It must be concluded that vasopressin has to be considered a very dangerous drug for horses and that it is not a therapeutic option in equine anaesthetic emergency cases. It can definitely not be understood how vasopressin could have been added to the list of substances essential for the treatment of equidae.

\section{Animal welfare statement}

The study was authorized by the Government of Upper Bavaria, Maximilianstrasse 39, 80538 Munich, Germany (Experiment No. 209.1/211-2531-19/05).

\section{References}

ASA (American Society of Anesthesiologists) (2013) http://www. asahq.org/

Aung K., Htay T. (2005) Vasopressin for cardiac arrest. Arch Intern Med $10(6), 17-24$

Babar S. I., Berg R. A., Hilwig R. W., Kern K. B., Ewy G. A. (1999) Vasopressin versus epinephrine during cardiopulmonary resuscitation: a randomized swine outcome study. Resuscitation 41, 185-192

Biondi-Zoccai G. G., Abbate A., Parisi Q., Agostoni P., Burzotta F., Sandroni C., Zardini P., Biasucci L. M. (2003) Is vasopressin superior to adrenaline or placebo in the management of cardiac arrest? A meta-analysis. Resuscitation 59, 221-224

Czupalla I., Gerhards H. (2013) Narkoserisiko bei Pferden - Eine retrospektive Studie anhand von 1.989 Narkosen. Risk of general anesthesia in horses - A retrospective study on 1.989 cases. Pferdeheilkunde 29, 729-738
Dembek K. A., Hurcombe S. D., Stewart A. J., Barr B. S., MacGillivray K. C., Kinee M., Elam J., Toribio R. E. (2014) Association of aldosterone and arginine vasopressin concentrations and clinical markers of hypoperfusion in neonatal foals. Equine Vet. J., doi: 10.1111/evj.12393. [Epub ahead of print]

Dickey E. J., McKenzie H. 3rd, Johnson A., Furr M. O. (2010) Use of pressor therapy in 34 hypotensive critically ill neonatal foals. Aust. Vet. J. 88, 472-477

Divers T. J. (2008) Shock and systemic inflammatory response syndrome. In: Orsini J. A., Divers T. J. (Ed.): Equine Emergencies, third ed., Saunders Elsevier, St. Louis, Missouri, 544-552

Dyson D. H., Maxie M. G., Schnurr D. (1998) Morbidity and mortality associated with anaesthetic management in small animal veterinary practice in Ontario. J. Am. Anim. Hosp. Assoc. 34, 325-335

Emergency Drug Charts (2008) In: Orsini J. A., Divers T. J. (Ed.): Equine Emergencies, third ed., Saunders Elsevier, St. Louis, Missouri, back side of the cover

Holcombe S. J. (2006) Shock: Pathophysiology, Diagnosis, and Treatment. In: Aver JA and Stick JA (Hrsg.): Equine surgery, third ed., Saunders Elsevier, St. Luois, Missouri, 1-9

Hurcombe S. D., Toribio R. E., Slovis N., Kohn C. W., Refsal K., Saville W., Mudge M. C. (2008) Blood arginine vasopressin, adrenocorticotropin hormone, and cortisol concentrations at admission in septic and critically ill foals and their association with survival. J. Vet. Intern. Med. 22, 639-647

Johnson T. (2003) Use of Vasopressin in Cardiopulmonary Arrest: Controversy and Promise. https://www.vetlearn.com 25, 448-451

Johnston G. M., Eastment J. K., Taylor P. M., Wood J. L. N. (2004) Is isoflurane safer than halothane in equine anaesthesia? Results from a prospective multicentre randomised controlled trial. Equine Vet. J. 36, 64-71

Kirker J. E. (2003) Pharmacology and adverse drug reactions. In: Manual of Equine Emergencies. (2nd edn). Orsini JA, Divers TJ (eds). Saunders, Philadelphia, London, New York, USA, 650-689

Kolm G., Fey K. (2011) Neonatale Sepsis. In: Fey K u. Kolm G (Hrsg.): Fohlenmedizin, Enke Verlag Stuttgart, 205-215

Krismer A. C., Dunser M. W., Lindner K. H., Stadlbaver K. H., Mayr V. D., Lienhart H. G., Arntz R. H., Wenzel V. (2006) Vasopressin during cardiopulmonary resuscitation and different shock states: a review of the literature. Am. J. Cardiovasc. Drugs 6, 51-68

Mayr V. D., Wenzel V., Voelckel W. G., Krismer A. C., Mueller T., Lurie K. G., Lindner K. H. (2001) Developing a vasopressor combination in a pig model of adult asphyxial cardiac arrest. Circulation 104, 1651-1656

Muir W. W., Hubbell J. A. E. (2009) Cardiopulmonary resuscitation. In: Muir W. W. and Hubbell J. A. E. (Hrsg): Equine Anesthesia, 2. Aufl., Saunders Elsevier St. Louis, Missouri, 418-429

Mulligan K. A., McKnite S. H., Lindner K. H. , Lindstrom P. J., Detloff B., Lurie K. G. (1997) Synergistic effects of vasopressin plus epinephrine during cardiopulmonary resuscitation. Resuscitation 35, 265-271

Palmer J. E. (2007) Neonatal foal resuscitation. Vet. Clin. North Am. Equine Pract. 23, 159-182

Positive list (List of Substances Essential for the Treatment of Equidae) (2013), Council Regulation (EG) Nr. 122/2013, Amtsblatt der Europäischen Union Nr. L 42/1, 13. Februar 2013

Raedler C., Voelckel W. G., Wenzel V., Krismer A. C., Schmittinger C. A., Herff H., Mayr V. D., Stadlbaver K. H., Lindner K. H., Königsrainer A. (2004) Treatment of uncontrolled hemorrhagic shock after liver trauma: fatal effects of fluid resuscitation versus improved outcome after vasopressin. Anesth. Analg. 98, 1759-1766

Reimold R. (2006) Vergleich der Wirkung von Blutdruck steigernden Medikamenten und Prüfung der Wirkung von Vasopressin bei Pferden in Isoflurannarkose. Diss. Med. Vet. München

Schmittinger C. A. (2003) Vasopressor agents or fluid resuscitation for the treatment of uncontrolled hemorrhagic shock, an experimental approach in a porcine liver trauma model. Diss. Med. Vet. Munich

Schmittinger C. A., Astner S., Astner L., Kössler J., Wenzel V. (2005) Cardiopulmonary resuscitation with vasopressin in a dog. Vet. Anaesth. Analg. 32, 112-114 
Stadlbaver K. H., Wagner-Berger H. G., Wenzel V., Voelckel W., Krismer A. C., Klima G., Rheinberger K., Pechlaner S., Mayr V. D., Lindner K. H. (2003a) Survival with full neurologic recovery after prolonged cardiopulmonary resuscitation with a combination of vasopressin and epinephrine in pigs. Anesth. Analg. 96, 1743-1749

Stadlbaver K. H., Wagner-Berger H. G., Raedler C., Voelckel W., Wenzel V., Krismer A. C., Klima G., Rheinberger K., Nussbaumer W., Pressmar D., Lindner K. H., Königsrainer A., Arntz R. (2003b) Vasopressin, but not fluid resuscitation, enhances survival in a liver trauma model with uncontrolled and otherwise lethal hemorrhagic shock in pigs. Anesthesiology 98, 699-704

Stashak T. S., Theoret C. L. (2008) Wound healing, management, and reconstruction. In: Orsini J. A. and Divers T. J. (Ed.): Equine Emergencies, third ed., Saunders Elsevier, St. Louis, Missouri, 189-236

Valverde A., Giguère S., Sanchez L. C., Shih A., Ryan C. (2006) Effects of dobutamine, norepinephrine, and vasopressin on cardiovascular function in anesthetized neonatal foals with induced hypotension. Am. J. Vet. Res. 67, 1730-1737

Wenzel V., Lindner K. H., Krismer A. C., Miller E. A., Voelckel W., Lingnau W. (1999) Repeated administration of vasopressin but not epinephrine maintains coronary perfusion pressure after early and late administration during prolonged cardiopulmonary resuscitation in pigs. Circulation 99, 1379-1384

Wenzel V., Voelckel W. G., Krismer A. C., Mayr V. D., Strohmenger H. U., Baubin A., Wagner-Berger H., Stallinger A., Lindner K. H. (2001) The new international guidelines for cardipulmonary resuscitation: an analysis and comments on the most important changes. Anaesthesist 50, 342-357

Wenzel V., Krismer A. C., Arntz R., Sitter H., Stadlbaumer K. H., Lindner K. H. (2004) A Comparison of Vasopressin and Epinephrine for Out-of-Hospital Cardiopulmonary Resuscitation. N. Engl. J. Med. 350, 105-113

\section{Erweiterte Zusammenfassung}

\section{Vasopressin ist für Pferde in Isoflurannar- kose lebensbedrohlich}

\begin{abstract}
Seit einigen Jahren wird Vasopressin für Notfallsituationen mit bevorstehendem Herz-Kreislaufstillstand als Notfallmedikament empfohlen. In verschiedenen Publikationen wird Vasopressin mit Adrenalin verglichen und es werden bei der Behandlung von bedrohlichem Blutdruckabfall und bei lebensbedrohlichen Schockzuständen Vasopressin Vorteile im Vergleich mit Adrenalin attestiert. Unter anderem soll die Durchblutung des Myokards besser aufrecht erhalten werden, als mit Adrenalin. In Fachbüchern wird Vasopressin auch für den Einsatz bei Pferden, insbesondere für Fohlen, aber auch für adulte Pferde empfohlen. Seit 2013 befindet sich Vasopressin zudem auf der Positivliste für die Behandlung von Equiden wesentlicher Stoffe.
\end{abstract}

Um zu prüfen, ob Vasopressin bei Pferden in Narkose bei Zwischenfällen Vorteile gegenüber Adrenalin haben könnte, wurde in der vorliegenden Arbeit ein Tierversuch durchgeführt (genehmigt von der Regierung von Oberbayern unter der Nummer 209.1/211-2531-19/05). Es wurde ein sogenannter Endversuch bei 10 Pferden durchgeführt, bei denen in Narkose während einer Operation oder Röntgenuntersuchung die Indikation für die Euthanasie gestellt werden musste. Bei den Pferden handelte es sich um 7 Wallache, 2 Stuten und ein Hengstfohlen. Das durchschnittliche Alter lag bei 14 Jahren (SD 8,5) und das durchschnittliche Gewicht bei 499,5 $\mathrm{kg}(\mathrm{SD} 105,1)$. Gründe für die Euthanasie waren eine septische Podotrochlitis nach Nageltritt, erhebliche knöcherne Ver- änderungen an der Hals- oder Brustwirbelsäule (3 Pferde), eine Beckenfraktur, eine Hüftgelenkarthrose, eine Kniegelenkzyste, ein intraabdominaler und ein intrakranieller Tumor sowie ein zur Erblindung des letzten verbliebenen Auges führendes Trauma. Nachdem in Narkose die Indikation für die Euthanasie gestellt worden war, wurde die Narkose jeweils etwas vertieft. Bei allen Pferden erfolgte eine engmaschige klinische Überwachung von Atemfrequenz, Atemzugvolumen, okularen Reflexen, Schleimhautfarbe, kapillärer Wiederfüllungszeit und digitaler Blutdruckpalpation. Zusätzlich erfolgte bei allen Pferden ein Monitoring mittels EKG, Pulsoximetrie, Kapnographie, direkter Blutdruckmessung und arterieller Blutgasanalyse. Bei 5 der Pferde wurde während der Vasopressingabe zusätzlich eine Ultraschalluntersuchung des Herzens ab dem Beginn der Vasopressingabe bis zum Herzstillstand durchgeführt und aufgezeichnet. Fünf der Pferde erhielten in Narkose Vasopressin als Bolus $(0,2 \mathrm{lU} / \mathrm{kg})$, weitere 5 Pferde erhielten eine Infusion mit Vasopressin $(0,08 \mathrm{IU} / \mathrm{kg}$ /min.). Bei dem ersten Pferd wurde die Narkose vor der Vasopressingabe vertieft, bis der Blutdruck auf $40 \mathrm{mmHg}$ abgefallen war. Nach der Injektion von Vasopressin starb das Pferd innerhalb kürzester Zeit. Auffallend waren hochgradig ischämische Schleimhäute. Um sicher zu gehen, dass die Pferde nicht durch die Narkosetiefe sterben, wurde bei den folgenden Pferden die Vasopressingabe schon bei einem Blutdruck von $60 \mathrm{mmHg}$ vorgenommen. Es stellte sich heraus, dass bei allen Pferden innerhalb von 30-60 Sekunden nach der Vasopressingabe (und unabhängig davon, ob eine Bolusinjektion oder Infusion vorgenommen wurde), zunächst ein Anstieg des Blutdrucks, gleichzeitig jedoch höchstgradig blasse Schleimhäute entstanden. Unter Ultraschallkontrolle der Herzaktion war eine rasch entstehende Herzdilatation mit Dekompensation und Herstillstand zu beobachten. Vier der 10 Pferde starben innerhalb von 5 Minuten und 4 weitere innerhalb von 10 Minuten nach der Vasopressingabe. Nur 2 Pferde konnten nach 10 Minuten noch euthanasiert werden. Ob diese die Narkose überlebt hätten, ist jedoch fraglich.

Es hat sich somit gezeigt, dass die periphere Vasokontriktion nach Vasopressingabe bei Pferden so erheblich ist, dass es zur Überlastung es Herzens und dadurch zum Herstillstand gekommen ist. Die für Vasopressin postulierte bessere Durchblutung der herzeigenen Gefäße kann für Pferde nicht nachvollzogen werden. Da auch bei der geringeren mittels Infusion verabreichten Vasopressindosis identische kardiovaskuläre Probleme auftraten, muss sehr eindringlich vor der Gabe von Vasopressin bei Pferden gewarnt werden. Selbst wenn bei einer geringeren Dosis weniger gravierende Folgen entstehen würden, hat Vasopressin offenkundig nur eine geringe therapeutische Breite und eine erschreckend letale Wirkung. Vor dem Einsatz von Vasopressin, der in Tierversuchen und auch bei realen bedrohlichen Situationen bei anderen Spezies offenbar hilfreich sein kann, kann beim Pferd nur abgeraten werden. Es ist vollkommen unverständlich, dass Vasopressin in manchen Lehrbüchern für das Pferd empfohlen wird. Es ist ebenso unverständlich, wie Vasopressin auf die Positivliste für die Behandlung von Equiden wesentlicher Stoffe gelangen konnte. Für lebensbedrohliche Narkosezwischenfälle mit Blutdruckabfall und Bradykardie oder Herzstillstand muss bei Pferden nach wie vor Adrenalin als Mittel der Wahl angesehen werden.

Schlüsselwörter: Vasopressin / Pferd / Isoflurannarkose / Herzdilatation / Herzstillstand / letal / Anästhesiologie 